811.163.41'373.611

811.163.41'36

811.163.41:929 Стакић М.

https://doi.org/10.18485/sj.2020.25.1.4

МИХАИЛО М. ШЋЕПАНОВИЋ

Универзитет у Београду

Филолошки факултет
Оригинални научни рад

Примљен: 15. 10. 2019.

Прихваћен: 15. 01. 2020.

\title{
ПЕРИНТЕГРАЦИЈА У МОРФОНОЛОШКИМ АНАЛИЗАМА МИЛАНА СТАКИЋА
}

У раду се, на основу увида у морфонолошке теме које су биле предмет научног интересовања професора Милана Стакића, указује на његов метод творбено-семантичке реконструкције и на улогу перинтеграције као битне творбене компоненте у, пре свега, именској деривацији. Радови професора Стакића показују да се за научно објашњење оних консонантских алтернација на додиру творбених морфема, које се не могу објаснити фонетским путем, за разрешење тог питања, мора посегнути за језичким осећањем, односно сагледати промену деривационог односа кроз перинтеграциони процес.

Кључне речи: морфонологија, дериват, деривација, гласовне промене, алтернације, перинтеграција, Милан Стакић.

1. Као задатак и основни циљ своје расправе Деривачиона фонетика именица и придева у јужнословенским језицима (1988) Милан Стакић одређује „да се утврди и објасни систем консонантских алтернација на саставу творбених морфема (деривационе основе и суфикса) изведених именица и придева у јужнословенским језицима и да се покаже у којој мери те алтернације осветљавају и друге елементе сложеног творбеног механизма, пре свега - структуру и порекло суфикса и њихових деривата”, а затим додаје „да би реч била изведена мора постојати у језичком осећању (курзив М. Ш.) мотивисана

*mihail.scepanovic@gmail.com 
веза - деривациони однос према другој основној речи истога корена" (Стакић 1988: 5, 6). Вредност ове расправе којом је професор Стакић ушао у српску дериватологију је, осим датог програма свог учења о творби речи, свакако и у чињеници да је овде професор приказао основе свог метода творбено-семантичке реконструкције на обимној језичкој грађи, а што је касније проверавао у новим темама. Истина, професор Стакић је остао у свом научном опредељењу дијахроничар, уверен да се замршена питања српске дериватологије не могу објаснити без сагледавања дугих историјских процеса кроз које су дате појаве настајале. Међутим, да би се осветлили синхрони пресеци у историјском развоју језика, Стакић, попут свог учитеља Радосава Бошковића, посеже за појмом и термином језичко осећање. Овај термин је, како примећује Радмило Маројевић, (2008: 165) „Бошковић несумњиво преузео од Белића” позивајући се на Михајловићев рад Белићеви погледи на природу и улогу језичког осећањ а (Михаиловић 1980: 13-20). Међутим, како прецизира Маројевић $(2008: 165,166)$ „у Бошковићевом учењу језичко осећање је добило кохерентније значење: 1) примењено је на синхроне пресеке у историјском развоју језика; 2) посматра се као дијалектичка категорија ; 3 ) променама у језичком осећању објашњавају се творбено-семантичке промене у морфемској и граматичкој структури речи; 4) језичко осећање је објективна категорија језичког развоја, а његов карактер се утврђује на основу анализе формалних и семантичких промена у структури речи и облика". Ови наводи нам индиректно показују колико је професор Стакић имао снаге и показао неумољиве упорности да остане и опстане на врлетној бошковићевској научној стази. Наиме, у свом раду Улога перинтеграчије у јужнословенској именској деривачији (1986: 177-183) Стакић појам језичко осећање, као и Бошковић, користи као битни критеријум творбено-семантичких промена у морфемској структури речи, наравно, у различитим формулацијама. Тако он у овом раду говори, на пример, „да језичко осећање никад не допушта творбену анализу Ило-чанин, већ увек и само Илоч-анин (178); ... докле год језичко осећање разлаже именице са завршетком -ачица на $-a ч+-u щ a$, односно док их доводи у мотивисану везу са именицама мушког рода на -ач, дотле наставак -ица има моциону функцију (179) ... у новом деривационом односу коштан : кост издвојила се алтернација $\mathrm{cm}-$ шт која за језичко осећање није била нешто ново (упор. ташта : macm)" (181)...

1.2. О улози перинтеграције, сем претходно наведеног рада и монографије коју смо поменули на почетку овог прилога, сусрећемо се и у низу радова професора Стакића, које ћемо овом приликом само поменути. То су, пре свега, радови: Видови дериваџионе основе именских речи у српском језику (1997); Деривачиона фонетика - у ужем смислу (1998); Придевски суфикс -ски (1999); Палатализације и алтернације задњонепчаних сугласника (2000); Дијахрони и синхрони аспекти гласовних закона (2002); Гласовни процеси и аналошка уопштавања (2003); Суфикс -арош (2005); Морфонолошка правила и изузеци 
(2007); Именички суфикс -ство (2019)... Сагледавајући ниску ових радова на временском луку од скоро четири деценије, онда се очитава унеколико и Стакићева верност научним чињеницама ослоњеним на опробан метод творбено-семантичке реконструкције. Другим речима он се понаша у лингвистичким анализама као верник бошковићевског приступа, кога, у својим аналитичким замасима, освежава новим решењима на новим примерима. Сагледавши историју питања, професор расветљава терминолошку апаратуру у својим текстовима, а потом опримерује своје аналитичке поставке - што је на неки начин и Стакићев методолошки образац. Тако нас и уводи у анализу грађе у, унеколико, за нашу тему, програмском тексту Улога перинтегращије у јужнословенској именској деривацији. У уводним редовима наводи: „У развитку прасловенских суфикса и њихових деривата перинтеграција је једна од основних творбених компонената. Најчешће се јавља као последица промењеног деривационог односа изведене и основне речи. Заправо, нови деривациони однос до којег долази услед унутрашњег семантичког богаћења изведених речи и перинтеграција - поновна морфемска подела изведеница - чине суштину словенске именске деривације. Без тих компонената творбеног механизма не би се могао разумети ни објаснити настанак и развитак словенских суфикса" (Стакић 1987: 177). Следи потом поглед у историју питања где се професор Стакић ослања на Бошковићева решења: „Моциони суфикс -ica постао је везом номинативног завршетка - $i$ и семантички празног суфикса, партикуле $-k a-$, „расловенски однос vblči-ca: vblkъ дао је, дакле, путем перинтеграиије наставак ica" (Бошковић 1978: 59). За промене у формалној структури суфиксалних морфема Бошковић се - како наводи Маројевић, (2008: 172) служи терминима перинтеграиија или (морфолошка) декомпозииија, док је на једном месту употребљен термин престројавање морфема (Бошковић 1978: 447).

За Бошковића је перинтеграција „формални језички процес” (1978: 145) којим се добија „нова подела на морфолошке елементе”, на пример овч-арица од овчар-ииа (1978: 64). Перинтеграцијом је добијен суфикс -епсе од еп којим се завршавао „општи део” (ime : imen-e) (131) ... Деминутивни суфикс -іса добијен је из односа deva : devica „перинтеграцијом и по новој језичкој интерпретацији” (274). Ова последња формулација - сматра Маројевић - сведочи да је Бошковић перинтеграцију сматрао последицом промене у језичком осећању.

За перинтеграцију је од значаја успостављање, како Бошковић каже, новог формантског контакта. Тако су првобитна имена Радов, Милов - скраћена лична имена од Radovanъ, Milovanъ - ,рано успоставила формантски контакт са скраћеним именима $\underline{P \hat{a} \partial, M \hat{u} л}$, услед чега је њихов првобитни основински завршетак - путем перинтеграције - постао секундарни именички суфикс $о в$ (1978: 390). 
Као најчешћу примену перинтеграције професор Стакић наводи примере развитка суфиксних деривата - сложених суфикса у самосталној употреби. У овом раду ћемо указати на Стакићево објашњење, и то убедљиво, настанка и функције неких карактеристичних именичких и придевских суфиксних деривата на материјалу из појединих јужнословенских језика.

За ову прилику издвајамо Стакићеву анализу деривата именичког суфикса:

-чан-ин: сх. Дољанчанин (Дољани), Дрварчанин (Дрвар), Загрепчанин (Загреб); словен. Ljubljančan (Ljubljana), Dunajčan (Dunaj), Mariborčan (Maribor); буг. пловдивчанин (Пловдив), берлинчанин (Берлин). Овај дериват општесловенског суфикса -jan-inъ проф. М. Стевановић (1970: 497-498 ) је објаснио семантичким појачавањем ранијих етника на -(a)u, нпр.: Загрепчанин : Загребац : Загреб. Било је покушаја да се овај суфикс издвоји из образовања типа Илочанин (Илок), Карловчанин (Карловац) (Ћорић: 1981:17, фуснота 9). Ово се - убедљив је професор Стакић - међутим, не би могло прихватити. Да би перинтеграцијом завршетак -(a)ц - ако се пође од другог примера - постао део суфикса у изведеној именици Карловчанин, морао би се променити деривациони однос, морало би, то јест, бити Карлов-чанин : Карлов, а пошто то није, будући да је Карловчанин „човек из Карловца”, јасно је да је деривациони однос овде Карловчанин : Карловач, да је творбена анализа изведенице само Карловч-анин и да се, према томе, овде није могао издвојити и осамосталити суфикс -чанин. То је још мање могуће у првом примеру Илочанин : Илок, језичко осећање никад не допушта творбену анализу Ило-чанин, већ увек и само Илоч-анин".

Ове Стакићеве анализе показују колико су српској дериватологији неопходни дијахроничари и палеослависти како би се ваљано указало на морфемске шавове деривата. То је професор зналачки показао на примерима Карловч-анин и Илоч-анин. И то пре четири деценије. Стакићеве аналитичке захвате илустроваћемо и примером још једног деривата именичког суфикса:

-ачища, -арица, -ашииа. У моционом односу -ач-ица : -ач у сх. језику осамосталио се суфикс -ачица који се функционално разликује од основног суфикса -ица. Наиме, док год језичко осећање разлаже именице са завршетком -ачица на -ач + -ица, односно док их доводи у мотивисану везу са именицама мушког рода на - $а ч$, дотле наставак -ица има моциону функцију, а њиме изведене речи означавају исто што и именице на -ач према којима стоје, разуме се - са променом рода. Када се, услед унутрашњег богаћења значења код ових именица, тај однос промени и када се именице са завршетком -ачица доведу у везу не према именицама м. рода на - $а ч$ него према основним речима од којих су ове изведене - издваја се суфикс -ачица са својим самосталним значењем које може бити разноврсно, али не и моционо: држачица „дрво за које се 
набијаља држи” (: држати), орачица „гужва на плугу” (: орати), равначища „у млину даска, која равна” (: равнати), сијачища „машина” (: сијати), косачица „машина” (: косити).

И у моционом односу -ар-ица : -ар осамосталио се, променом деривационог односа и перинтеграцијом, дериват -арица - браварииа „појата у којој брави стоје” (брав), глинарица „црв који живи у глини” (глина), ловарица „ловна пушка" (лов, ловити), мисарица „кошуља за мису” (миса), мишарица „змија” (миш), млинарица „риба која живи око млина” (млин), мљечарица „змија” (млијеко), мљекарица „крава која има доста млијека” (млијеко), мрциињарица „птица која једе мрцину” (мрцина), мрежарица „а) лађа, б) риба” (мрежа), овчарица „стаја” (овца), пачарица „кокош која води пачиће” (патка, паче), пчеларица „колач за пчеле” (пчела), пјескарица „пјешчана ура” (пијесак), пјесмарица „књига у којој су пјесме” (пјесма), поточарица „поточна риба" (поток), рачарица „торба” (рак), рибарица „птица, лађа” (риба), сламарица (слама), тикварица „пита с месом из тикве” (тиква), винарииа „брод, суд” (вино), житарицуа „лађа” (жито)” (Стакић 1987: 179).

Бошковићево тумачење овог суфикса (1978: 63-64) Стакић употпуњује, како видимо, низом примера. Из ове перспективе је занимљиво колико је наведених примера данас сачувано у језичком осећању. Мало, и то пре свега, у локалној употреби. Ово је, свакако, драгоцен подстрек за поглед у дијалекатске речнике. На пример млинарица у Дробњаку је била „мања врећа за пренос жита у млин”, док је пјемарица сачувана захваљујући Вуку.

Занимљиво је погледати и однос сејачица - сејач (машина: „купио сејач за кукуруз”). Језичко осећање, очито успоставља моциони однос. Мушкарци су обично сејали.

Овај исечак наведених примера из рада професора Стакића, свакако вреди употпунити новом грађом како би се сагледали савремени процеси перинтеграције код именичких суфиксалних деривата, нарочито деминутивних и аугментативних форми.

Када је реч о дериватима придевских суфикса из рада, тада младог Стакића, издвајамо, како он каже, напомену, а она је, свакако, много више од напомене. То је напомена „о алтернацијама испред суфикса -ан $(<-$ е̌nъ) и о евентуалној улози перинтеграције у њиховом објашњавању. Поред фонетски разумљивих алтернација: $к-ч$ (сјерчан „што је од сијерка" : сијерак), $c \kappa-u m / /$ шч (воштан и вошчан „од воска”: восак), г-ж (рожан „од рога”: рог), зг -жд

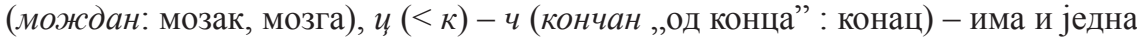
необична и неочекивана $\mathrm{cm}-$ шт (тјешчан : тијесто), односно $\mathrm{cm}-$ шт // шч (коштан и кошчан: кост) коју су неки научници објаснили помоћу суфикса -jan. Ова се алтернација, међутим, може објаснити и без прејотованог облика -jan (чије порекло ионако нико није покушао да објасни). Ако, наиме, упоредимо, 
с једне стране, придеве коштан $=$ кошчан $=$ костен (: коска, кост), тршчан = трстен (трска, трст) - наћи ћемо их у Rječniku JAZU - и, с друге стране, тјештан = тјестен (тијесто), запазићемо следеће: а) сви они имају старији и очекивани облик на -ен (костен, трстен, тјестен); у свом даљем развитку именице кост и трст добиле су суфикс -ька са деминутивним значењем које је касније избледело - сасвим обична појава код овог суфикса - тако је облик трска, изједначивши се са основом речи $т p c m$, ову готово потиснуо из употребе, док се код коска десило нешто друго - негде је сачувала деминутивно значење, а негде значи исто што и кост (упор. Речник САНУ), па или је ову потиснула из употребе, или је сама била потиснута од основне речи; б) од именица коска <*kostbka и трска <*trstbka изведени су нови градивни придеви кошчан и тршчан, од којих је први добио и паралелни облик коштан, а други (тричан) није га добио - или због ређе употребе, или због гласовног састава (због $m$ у суседном слогу); в) у говорима где је кост потиснула из употребе облик коска у основном значењу - у новом деривационом односу коштан : кост издвојила се алтернација $\mathrm{cm}-$ шт која за језичко осећање и није била нешто ново (упор. ташта : таст); и г) употреба различитих облика Stoffadjektiva костен и коштан (: кост) напоредо са тјестен (: тијесто) довела је, или је могла довести, до преношења алтернације $c m-u m$ и на овај други придев тако да се поред тјестен јави и тјештан : тијесто (које, истина, нема - нити се зна да је имало - облик *těska < *těst-bkai, али ни облик muјесто није и једини код ове именице - уп. muјест м. род и тијеста ж. род са истим значењем у Rječniku JAZU)" (Стакић 1986: 181).

Ова Стакићева напомена је, као што рекосмо, више од тога. Наиме, овде је аутор показао да се, без праћења историјског развоја одређене језичке појаве, не може доћи до убедљивог решења. Кад то наводим, мислим на следеће аргументе: аутор полази од старијих облика (а) који му даље отварају перспективу везе са основним именичким ликовима који су добили деминутивни суфикс, који је своје деминутивно значење, у зависности од употребе неједнако чувао, преузимајући тако основно. Тако је даље (б) било омогућено стварање нових градивних придева и издвајање алтернације. За граматичку литературу - математички прецизно и бошковићевски концизно. Уједно овај цитат, а природа овог прилога је да се мора ослањати на цитате, како би се што уверљивије показали научни поступци и истраживачки домети професора Стакића, што уједно показује и његову методолошку поузданост. Из овога следи да је професор Милан Стакић већ у овом, по свој прилици, програмском тексту показао да се перинтеграцијом објашњава порекло највећег броја прасловенских именских суфикса. Даље, њоме се објашњавају и деривати прасловенских суфикса, али тада перинтеграцији увек претходи промена деривационог односа, а разлагање морфема увек се врши по морфемском шаву, док дериват настаје богаћењем основног суфикса на рачун основе. 
3. У часопису Српски језик за 2019. годину професор Милан Стакић је објавио расправу скоро монографског типа Суфикс -ство у српском језику (357-373). У уводним напоменама аутор износи сопствене истраживачке задатке, што непосредно говори о истаживачкој озбиљности самог аутора као и о стремљењима у истраживачком поступку. „Објаснити један суфикс значи говорити о више појединости: о пореклу тога суфикса, о значењу њиме изведених речи, о мотивним речима и њиховим творбеним основама, о деривационом односу мотивних и мотивисаних речи, о суфиксним аломорфима повезаним са гласовним алтернацијама на морфемском шаву творбене основе и суфикса, о суфиксним дериватима и њиховом начину и узроку јављања, о значењу помоћу њих изведених речи, о продуктивности датог суфикса, о његовим семантичким синонимима и, напослетку, о гласовним алтернацијама и фонемском уобличавању изведеница" (Стакић 2019: 357). Све задато професор Стакић примењује на суфикс -ство, и на њиме изведене именице, а све то ослањајући се на обимну грађу прикупљену из шестотомног Речника српскохрватскога књижевног језика. Истина за потребе овог прилога нас интересује само сегмент о суфиксалним дериватима и о њиховом начину и узроку јављања. Међутим, претходним цитатом указујемо на методолошку јасност и научну озбиљност самог аутора, сад већ, као научника, зрелог Милана Стакића. У раду су сви задаци до танчина испоштовани. За историју питања изнесена су мишљења П. Скока, А. Мејеа, А. Белића, В. Вондрака и других.

Овде Стакић показује да, за разлику од аломорфа, суфиксални деривати настају перинтеграцијом као последица унутрашњег богаћења значења изведеница са суфиксом -ство. И никад не значе исто што и изведеница са основним суфиксом. Иако их Клајн назива сложеним суфиксима, Стакић подвлачи да су то деривати суфикса јер су настали променом деривационог односа и перинтеграцијом тј. долазило је до издвајања суфиксалних деривата: говедарство у значењу „чување говеда, посао говедара” творбено се доводи у везу са говедар и морфемски се разлаже на говедар-ство, а у промењеном значењу „грана привреде” мења се деривациони однос и творбена структура: говед-арство и сл.

4. Овај прилог представља покушај да се прикаже, на основу временских крајева лука, Стакићево учење о грађењу речи, а пре свега, о суфиксацији и улози перинтеграције у творењу нових деривата. Осветљен је, барем делимично, на основу природе Стакићевих доказа у анализама, степен уверљивости појединих тумачења кроз призму различитих тумачења у историјском следу. Чини се да је то веома битно за приказивање Стакићевог приступа морфонолошким темама и проблемима који се јављају у српској дериватологији. Свакако, стиче се утисак да Стакићеви радови и расправе везане за конкретна питања и проблеме творбе речи у српском језику, имају несумњив значај за разрешавања доста нагомиланих питања везаних за творбу речи у српском 
језику, која се не могу раздвојити без ваљаних морфонолошких анализа. С те стране, научно дело Стакићево представља значајан допринос у самој остварености, али и путоказ будућим истраживачима за она питања која је професор оставио отвореним. Управо научна оствареност чини Милана Стакића узорним педагогом, професором и истраживачем.

\section{ЛИТЕРАТУРА}

Белић 1999: А. Белић, Историја српског језика (Изабрана дела Александра Белића, т. 4), Београд: Завод за уџбенике и наставна средства.

Бошковић 1978: Р. Бошковић, Одабрани чланци и расправе, Титоград: Црногорска академија наука и умјетности, Посебни радови, књига I.

Маројевић 2008: Р. Маројевић, Српски језик данас, Београд - Бања Лука: Бард-фин - Романов.

Михаиловић 1980: Љ. Михаиловић, Белићеви погледи на природу и улогу језичког осећања, Научни састанак слависта у Вукове дане, 9, 13-20.

Стакић 1986: М. Стакић, Улога перинтеграције у јужнословенској именској деривацији, Научни састанак слависта у Вукове дане, 16/1, $177-183$.

Стакић 1988: М. Стакић, Дериваџиона фонетика именица и придева у јужнословенским језицима, Београд: Филолошки факултет.

Стакић 1997: М. Стакић, Видови деривационе основе именских речи у српском језику, Кьижевности и језик, 45/4, 11-16.

Стакић 1998: М. Стакић, Деривациона фонетика - у ужем смислу, Српски језик, III, 109-124.

Стакић 1999: М. Стакић, Придевски суфикс -ски, Српски језик, IV, 409-418.

Стакић 2000: М. Стакић, Палатализације и алтернације задњонепчаних сугласника, Српски језик, V, 339-356.

Стакић 2002: М. Стакић: Дијахрони и синхрони аспекти гласовних закона, Српски језик, VII, 251-262.

Стакић 2002: М. Стакић, Морфонологија и дериващија (чланщи и расправе), Београд: Филолошки факултет, Научно друштво за неговање и проучавање српског језика.

Стакић 2003: М. Стакић, Гласовни процеси и аналошка уопштавања, Зборник радова са научног скупа „, лингвистички скуп Бошковићеви 
дани”, Подгорица: Црногорска академија наука и умјетности, 281-287.

Стакић 2005: М. Стакић, Суфикс -арош, Београд: Србистички прилози (Зборник радова у част професора Славка Вукомановића), 243-248.

Стакић 2007: М. Стакић, Морфонолошка правила и изузеци, Научни састанак слависта у Вукове дане, 35/3, 45-57.

Стакић 2010: М. Стакић, Морфо(но)лошке теме, Београд: Друштво за српски језик и књижевност Србије.

Стакић 2019: М. Стакић, Именички суфикс -ство у српском језику, Српски језик, XXIV, 357-374.

Ћорић 1981: В. Ćorić, Imenički sufiksi s inicijalnim $\check{C}$, Сарајево: Къижевни језик, год. Х, бр. 4, 15-18.

\section{ПЕРЕРАЗЛОЖЕНИЕ В МОРФОНОЛОГИЧЕСКИХ АНАЛИЗАХ МИЛАНА СТАКИЧА}

$$
\text { Резюме }
$$

На основании обзора морфонологических тем, являющихся предметом научных интересов профессора Милана Стакича, в работе указывается на роль переразложения в качестве основного словообразовательного компонента, в первую очередь, касательно деривации имен.

Исследования профессора Стакича показывают, что научное обоснование при тех чередованиях согласных на стыке словообразовательных морфем, которые не подлежат объяснению фонетическим способом, необходимо воспользоваться языковым чутьем, условившим изменение деривационных отношений, а в дальнейшем и процессы переразложения.

Ключевые слова: переразложение, морфонология, языковое чутье, дериват, дериватология, Милан Стакич. 